\title{
Trimodality Treatment in Malignant Pleural Mesothelioma - An Ordeal or The Real Deal?
}

\section{$\underline{\text { AUTHORS }}$}

1. Naveen Mummudi

Department of Radiation Oncology,

Tata Memorial Centre, Homi Bhabha National Institute, India

Email: mummudinb@tmc.gov.in

2. Asfiya Khan

Department of Radiation Oncology,

Tata Memorial Centre, Homi Bhabha National Institute, India

Email:asfiya.khn@gmail.com

3. Anil Tibdewal

Department of Radiation Oncology,

Tata Memorial Centre, Homi Bhabha National Institute, India

Email:aniltibdewal@gmail.com

4. Rajiv Kumar

Department of Pathology,

Tata Memorial Centre, Homi Bhabha National Institute, India

Email: rajiv.kaushal@gmail.com

5. Sabita Jiwnani

Department of Thoracic surgery,

Tata Memorial Centre, Homi Bhabha National Institute, India

Email:sabitajiwnani@gmail.com

6. George Karimundackal

Department of Thoracic surgery,

Tata Memorial Centre, Homi Bhabha National Institute, India 
medRxiv preprint doi: https://doi.org/10.1101/2020.05.13.20087189; this version posted May 18, 2020. The copyright holder for this preprint (which was not certified by peer review) is the author/funder, who has granted medRxiv a license to display the preprint in perpetuity. All rights reserved. No reuse allowed without permission.

Email: gkarimundackal@gmail.com

7. CS Pramesh

Department of Thoracic surgery,

Tata Memorial Centre, Homi Bhabha National Institute, India

Email: cspramesh@gmail.com

8. Jai Prakash Agarwal

Department of Radiation Oncology,

Tata Memorial Centre, Homi Bhabha National Institute, India

Email:agarwaljp@tmc.gov.in

\section{CORRESPONDING AUTHOR:}

Jai Prakash Agarwal,

Department of Radiation Oncology,

Tata Memorial Centre, Homi Bhabha National Institute, India

Email: agarwaljp@tmc.gov.in

Phone number: +91-022-2417-7000 (Extension - 6791)

Short running title: Trimodality treatment in mesothelioma

Keywords: Malignant pleural mesothelioma, trimodality treatment, hemithoracic radiation therapy 
medRxiv preprint doi: https://doi.org/10.1101/2020.05.13.20087189; this version posted May 18, 2020. The copyright holder for this preprint (which was not certified by peer review) is the author/funder, who has granted medRxiv a license to display the preprint in perpetuity.

\begin{abstract}
$\underline{\text { ABSTRACT }}$
BACKGROUND: Malignant Pleural Mesothelioma is an uncommon and aggressive disease associated with asbestos exposure. Management of MPM is complex and controversial as there is paucity of good quality evidence. Multimodality treatment with surgery, systemic therapy and radiation therapy is an option in non-metastatic MPM. We intend to analyze toxicity and outcomes in patients who received trimodality treatment for non-metastatic MPM at our institution.
\end{abstract}

METHODS and MATERIALS: We reviewed the electronic medical records of surgically managed MPM patients at our institution in the last decade. Patient details, disease characteristics and treatment information were retrieved from the institutional electronic medical record and radiation oncology information system. Dosimetric parameters of target volume and organs at risk were documented from Eclipse workstation (v13.6, Varian medical systems). SPSS was used for statistical analysis.

RESULTS: Between January 2008 and October 2018, 21 patients (17 male and 4 female) underwent surgery for MPM - all but 2 patients underwent extra-pleural pneumonectomy (EPP). Primary was located in the right and left in 11 and 10 patients respectively. Epithelioid MPM was the commonest histology (17 patients - 81\%). Resection was R0 in 18 patients and R2 in 2 patients. Four patients had minor complications like wound erythema, wound seroma with cellulitis and hypotension and 8 Patients had major complications like pneumonia, rib fracture, pulmonary hypertension and pulmonary stump thrombus. All patients received neoadjuvant Pemetrexed/platinum doublet chemotherapy, except for 2. Fourteen patients received adjuvant hemithoracic RT; of these, 2 underwent treatment elsewhere and 2 were treated with conventional technique. Ten patients treated with conformal technique at our institute and dosimetric data was available for analysis. Average time to start RT after surgery was 51 days (range 32-82 days). All patients were treated with conformal technique using IMRT/VMAT to a dose of 45Gy in 25 fractions; one patient received a further boost of 5.4Gy. Mean overall RT duration was 35 days (range 30 - 42 days). Acute toxicity was uncommon; Grade I/II Pneumonitis was seen in 4 patients. One patient developed grade III acute lung toxicity unrelated to RT. At a median follow up of 25 months, 8 patients developed progressive disease. Eight 
medRxiv preprint doi: https://doi.org/10.1101/2020.05.13.20087189; this version posted May 18, 2020. The copyright holder for this preprint (which was not certified by peer review) is the author/funder, who has granted medRxiv a license to display the preprint in perpetuity. All rights reserved. No reuse allowed without permission.

patients had died, of whom six died due to disease and two died in immediate post op period. Two-year DFS and OS were $58 \%$ and $73 \%$ respectively.

CONCLUSION: In spite of the extensive surgery and complex hemithoracic RT, we demonstrated excellent dosimetric, toxicity profile and favorable outcomes in non-metastatic MPM. 
medRxiv preprint doi: https://doi.org/10.1101/2020.05.13.20087189; this version posted May 18, 2020. The copyright holder for this preprint (which was not certified by peer review) is the author/funder, who has granted medRxiv a license to display the preprint in perpetuity.

All rights reserved. No reuse allowed without permission.

\section{INTRODUCTION}

Malignant Pleural Mesothelioma (MPM) is an uncommon disease originating in the mesothelial surface of pleura and has strong association with asbestos exposure. Prior thoracic radiation, exposure to erionite (a mineral found in gravel road) and few genetic mutations (BRCA1-associated protein-1, BAP1 gene) have also been linked as a risk factor in the development of MPM. Mesothelioma is an aggressive malignancy as most patients present with advanced disease. Management of MPM is complicated and controversial as there is paucity of good quality evidence. Also outcomes have remained dismal despite aggressive treatment strategies with median survival of less than 2 years(1,2). Tri-modality treatment with surgery, systemic therapy and radiation therapy is an option in stage I-III MPM, but not widely adopted, in view of the complexity of the procedure, associated toxicity and absence of strong evidence to support its practice $(3,4)$. Analysis from a hospital registry based database showed that the median survival was $4.8,11.3,15.3$, and 19.9 months, respectively, with no therapy, chemotherapy alone, chemotherapy followed by surgery, and tri-modality therapy including radiation therapy $(5)$.

Surgery in MPM is performed to achieve maximal cyto-reduction, as complete microscopic surgical resection is highly unlikely, and MPM almost always recurs after surgery alone. Surgical resection options in MPM includes pleural decortication, which involves removal of involved pleura along with gross tumour and extra pleural pneumonectomy (EPP) which is the en-bloc removal of involved visceral and parietal pleura, ipsilateral lung, ipsilateral diaphragm and the pericardium. Lack of robust data has made the choice between the two surgical procedures contentious(6). To improve resectability and local control rates, neoadjuvant chemotherapy is administered along with aggressive surgery and post-operative radiotherapy(4). Postoperative radiotherapy (RT) is not only an area of debate, but also extremely challenging as radiation fields have to cover a large and anatomically complex volume extending from the apex of the lung to inferiorly, the costo-diaphragmatic recesses and medially, including the diaphragmatic crus down to the lumbar vertebrae(7). The Swiss SAKK 17/04 trial is the only controlled prospective trial to investigate the role of postoperative RT as part of tri-modality 
medRxiv preprint doi: https://doi.org/10.1101/2020.05.13.20087189; this version posted May 18, 2020. The copyright holder for this preprint (which was not certified by peer review) is the author/funder, who has granted medRxiv a license to display the preprint in perpetuity.

All rights reserved. No reuse allowed without permission.

therapy in MPM did not show any benefit with RT(8). However, the negative results have to be interpreted with caution because of the small number of patients, heterogeneity of RT techniques, lack of a central plan review and a high incidence of death in irradiated patients. The aggressive behaviour of the disease coupled, toxic treatment modalities and dearth of good quality evidence makes MPM one of the obstinate malignancies to treat.

At our institution, a tertiary care oncology centre, we deliver tri-modality treatment with neoadjuvant chemotherapy followed by extra-pleural pneumonectomy and adjuvant hemithoracic radiation in patients with non-metastatic MPM. In this report, we analyse and describe the radiation technique, dosimetric parameters, toxicity, outcome of patients who underwent trimodality treatment over the past ten years at our centre.

\section{MATERIALS AND METHODS}

This single institutional retrospective observational study was approved by the institutional review board and informed consent was waived. From a prospectively maintained database, we reviewed patient details, disease characteristics and treatment information of surgically managed non-metastatic MPM patients treated in the last ten years at our institution. Inclusion criteria consisted of previously untreated histologically proven MPM of all subgroups, clinical stage T1-3,N0-2 disease according to AJCC 8th edition. All clinical management decisions were discussed and decided in a multidisciplinary tumour board prior to initiation of treatment.

Between January 2008 and October 2018, we identified 21 consecutive patients with nonmetastatic MPM who underwent radical curative surgery. Patients underwent either an extrapleural pneumonectomy or lung sparing surgery like pleural decortication .

Patients were planned for2-3 cycles of neoadjuvant chemotherapy with pemetrexed/platinum doublet chemotherapy. Patients received cisplatin $(75 \mathrm{mg} / \mathrm{m} 2)$ or carboplatin (area under curve, 5) and pemetrexed $500 \mathrm{mg} / \mathrm{m} 2$ every 3 weeks followed by response assessment with CECT Thorax. Following physical and pulmonary evaluation, patients were then planned for further surgical management, if fit. 
medRxiv preprint doi: https://doi.org/10.1101/2020.05.13.20087189; this version posted May 18, 2020. The copyright holder for this preprint (which was not certified by peer review) is the author/funder, who has granted medRxiv a license to display the preprint in perpetuity.

\section{RT Technique}

Patients planned for postoperative adjuvant hemi-thoracic RT were immobilized and simulated in supine position with both arms overhead. Planning CT scan was obtained from the level of cricoid cartilage till second lumbar vertebra. The entire ipsilateral hemi thorax was contoured as the clinical target volume (CTV), which included parietal and visceral pleura, diaphragmatic insertion, involved lymph node station and recesses. CTV superiorly extended from the superior border of T1 vertebral body to the insertion of diaphragm inferiorly. Laterally, the parietal pleura was covered along the ribs. Medially, the mediastinal pleural attachments were included till the hilum. PTV was generated with an isotropic $7 \mathrm{~mm}$ margin to CTV.The dose prescribed to the Planning target volume was 45Gy in 25 fractions with boost dose to areas of high risk of failure.Dose constraints to contralateral lung were a mean lung dose less than $8 \mathrm{~Gy} ; \mathrm{V}_{5 \mathrm{~Gy}}<60 \%$ and $\mathrm{V}_{20 \mathrm{~Gy}}$ of $4-10 \%$. Treatment planning was done using AAA or a convolution/superposition algorithm. Treatment was delivered in a linear accelerator using static intensity modulated radiation therapy (IMRT) or volumetric modulated arc therapy (VMAT).

Data was retrieved from institutional electronic medical record and Radiation Oncology Information System, indigenous databases that record the course of patient history, investigations and treatment received at the institution. Radiation dosimetric parameters of target volume and organs at risk were documented from Eclipse workstation (v13.6, Varian medical systems). Toxicity was scored with the Common Terminology Criteria for Adverse Events version 4.0. Actuarial rates of disease free survival (DFS) and overall survival (OS) were estimated by using the Kaplan-Meier method and compared with log-rank tests. survival outcomes were estimated with the Kaplan-Meier method. SPSS was used for statistical analysis.

\section{RESULTS}

Patient and demographic characteristics are listed in Table 1. All patients except for 2 received NACT; ten patients received pemetrexed and cisplatin combination while the rest received pemetrexed and carboplatin. EPP was the predominant surgery performed (90\%) and only 2 underwent decortication. Complete resection was possible in 18 patients (86\%). Four patients had minor post-operative complications like wound erythema, wound seroma with 
medRxiv preprint doi: https://doi.org/10.1101/2020.05.13.20087189; this version posted May 18, 2020. The copyright holder for this preprint (which was not certified by peer review) is the author/funder, who has granted medRxiv a license to display the preprint in perpetuity.

All rights reserved. No reuse allowed without permission.

cellulitis and hypotension; eight patients had major complications like pneumonia, rib fracture, pulmonary hypertension and pulmonary stump thrombus. All patients had macroscopic complete resection except for 2 patients who had $\mathrm{R}+$ resection. Commonest histology encountered was epithelioid mesothelioma $(81 \%)$.

Adjuvant hemithoracic radiation was planned in 14 patients; two patients received RT at a different centre and dosimetric parameters were not available for analysis. Two other patients received treatment using conventional antero-posterior portals and were also not included in the dosimetric analysis. All of the remaining 10 patients were treated with conformal technique; 6 patients were treated with intensity modulated radiation therapy (IMRT) and the rest treated with Volumetric modulated arc therapy (VMAT)(see Figure 1).

Average time to start RT after surgery was 51 days (range 32-82 days). Mean dose delivered was $45 \mathrm{~Gy}$ (range 34 to $50.4 \mathrm{~Gy}$ ) in $1.8 \mathrm{~Gy}$ per daily fraction size. Only one patient did not complete treatment and another patient received a further 5.4Gy boost to high risk tumour bed. Mean duration of RT was 35 days (range 30-42 days).

Dosimetric characteristics are shown in Table 2. Mean Dose to contralateral Lung was $5.95 \mathrm{~Gy}$; volume of lung receiving 5 and $10 \mathrm{~Gy}$ were $43 \%$ and $7.5 \%$ respectively. The mean heart dose was $20.55 \mathrm{~Gy} ; \mathrm{V}_{30 \mathrm{~Gy}}(\%)$ received by heart was $26 \%$. Mean dose to liver was significantly less at 14Gy. As expected, dose received by heart was more in left sided primary whereas liver received comparatively more dose in right sided primary.

RT Toxicity (see Table 3)

Grade I oesophagitis was seen in 3 patients and one patient had Grade II oesophagitis (all left sided tumours). No patients developed grade 3/4 esophagitis. Grade I / II pneumonitis was seen in 4 patients. One patient developed Grade III acute lung toxicity and further treatment was stopped at 34Gy; however, on radiological evaluation, there was no evidence of radiation induced pneumonitis. No patient developed chronic pneumonitis or other late toxicity.

Survival

Median follow up was 25 months (IQR 13.5-32.5 months) for the entire cohort. Eight patients developed progressive disease, of whom 2 had local disease recurrence, 3 had local and 
medRxiv preprint doi: https://doi.org/10.1101/2020.05.13.20087189; this version posted May 18, 2020. The copyright holder for this preprint (which was not certified by peer review) is the author/funder, who has granted medRxiv a license to display the preprint in perpetuity.

All rights reserved. No reuse allowed without permission.

distant metastases, three more had peritoneal disease recurrence only. Of the 14 patients who received RT, there were 6 patients with disease recurrence - one with local disease only, 2 with local and distant.

At last follow up, 13 patients were alive of whom ten were alive with controlled disease; three patients had received systemic chemotherapy for metastatic disease. Eight patients had died, of whom six died due to disease and two died in the immediate post-operative period; 30day mortality after surgery was $9.5 \%$. In the RT cohort, there were 5 deaths, of which one alone was unrelated to the disease.

One year and 2-year disease free survival (DFS) were 65\% and 58\% respectively (Figure 2). Median PFS was significantly better in patients with epithelioid histology $(\mathrm{p}<0.001)$, but was not different for $\mathrm{T}$ or $\mathrm{N}$ stage. DFS did not differ for type of surgery, chemotherapy agents or RT delivery. Median overall survival (OS) was 41 months for the entire cohort; 1-yr and 2-yr OS were $90 \%$ and $73 \%$ respectively (Figure 3a). Patient receiving RT had a numerically better OS than those who did not receive (41 months vs 18 months; $p=0.18$ ) (Figure 3b); patients with node negative disease had a trend towards better OS $(\mathrm{p}=0.07)$. None of the other clinical factors was predictive for survival.

\section{DISCUSSION}

Given the rarity and aggressive behaviour, the optimal management of MPM remains controversial and best managed by a multidisciplinary team with experience(9). Patients with stage I-IIIA (AJCC $8^{\text {th }}$ edition) are offered surgical management if they are medically fit and possess adequate pulmonary reserve. However, the choice of surgical procedure remains mired in controversy. Few meta-analysis(10-12) have shown that EPP is associated with higher morbidity and mortality compared to pleurectomy or decortication (P/D) and also have inferior survival outcome(13). MARS, a randomized study comparing EPP and P/D observed higher surgical morbidity in EPP arm. However, the study had relatively small number of patients and was intended primarily to study the feasibility of randomizing 50 patients over 1 year for surgery(6). Currently NCCN considers both surgical options as reasonable and the decision to choose one over the other dependant on factors like histology, stage, pulmonary reserve, surgical 
medRxiv preprint doi: https://doi.org/10.1101/2020.05.13.20087189; this version posted May 18, 2020. The copyright holder for this preprint (which was not certified by peer review) is the author/funder, who has granted medRxiv a license to display the preprint in perpetuity.

All rights reserved. No reuse allowed without permission.

expertise, availability of adjuvant treatment options. At our institution, non-metastatic MPM patients are routinely discussed in a multidisciplinary meeting to decide on surgical and adjuvant therapy.

Adjuvant hemithoracic radiation therapy has been shown to decrease the risk of locoregional recurrences after surgery for MPM. Data from MD Anderson Cancer Center showed that postoperative radiation therapy after EPP results in superior local control(14). In a recently published analysis of the US national cancer database (NCDB), improved survival was associated with trimodality treatment compared with surgical intervention and chemotherapy alone(15). While radiation can provide durable local control, the presence of critical structures such as the contralateral lung, heart, kidney, spleen and the complex nature of the target volume has traditionally limited the ability to safely deliver RT for patients with MPM. Presence of collection in the hemithorax, seroma in the chestwall, shift of mediastinum leads to tissue inhomogeneity, lateral electronic disequilibrium at tissue interfaces which results in significant inaccuracies in dose calculation accuracy and distribution(16).

Even with the practice of IMRT, early experience of hemithoracic RT with IMRT resulted in increased fatal pneumonitis(17), possibly because of increased "low-dose spillage" into the contralateral lung. Recent advances and technological sophistication in RT planning and delivery have resulted in increased conformity of radiation dose culminating in expanded applications of RT for patients with MPM. Compared with three dimensional conformal RT (3DCRT), IMRT has been shown to improve the planning target volume coverage(18). Although a modified electron-photon technique has the potential to minimize dose to contralateral lung and other structures when compared with IMRT(19), associated dose inhomogeneity, unpredictable target coverage may lead to increased loco-regional failure. In the ten patients we treated at our institute, we observed an average conformity index of 0.98 while the mean heterogeneity index was 0.07 , highlighting excellent target coverage and dose homogeneity.

In all the cases, we were able to attain the stringent dose constraints set to the contralateral lung, liver and the kidneys. Although this could be explained by the lower total dose of 45Gy that we used, higher doses of RT is indicated only in case of macroscopic residual disease and may potentially lead to increased toxicity with no additional benefit in local control. In a study of 86 patients undergoing trimodality therapy using IMRT, the authors observed low 
medRxiv preprint doi: https://doi.org/10.1101/2020.05.13.20087189; this version posted May 18, 2020. The copyright holder for this preprint (which was not certified by peer review) is the author/funder, who has granted medRxiv a license to display the preprint in perpetuity.

All rights reserved. No reuse allowed without permission.

rates of grade 3 or more esophagitis (16\%) and pneumonitis (12\%) without compromising the target coverage(20). We implemented strict planning guidelines with emphasis on the OAR dose constraints which has resulted in improvement in overcoming acute and late toxicities. We noted low incidence of acute and chronic clinical esophagitis and pneumonitis. The only patient in whom RT was interrupted for respiratory symptoms did not show any radiological evidence of pneumonitis at follow up. The recent patients in our cohort were treated with VMAT, which is a newer technique to deliver continuous, dynamic, modulated radiation over a rotational arc of gantry which allows for even better dose conformality than static IMRT with shorter treatment times(21,22).

Since routine use of prophylactic radiotherapy to prevent tract metastases was not shown to be beneficial post large-bore thoracic interventions in patients with metastatic MPM(23), we do not include the surgical scar in our target volume. In our series, of the three patients who failed locally after receiving RT, there was no incidence of tract site deposit.

In a multi-centre phase II randomized trial, addition of hemithoracic RT did not result in any significant difference in local-regional progression-free or overall survival(8,24). However the study was severely underpowered to detect any difference between the groups. Incidentally, we did not find any improvement in survival parameters with the delivery of RT. The two year DFS and OS for the entire cohort in our series was $58 \%$ and $73 \%$ respectively. For the patients who received RT, the corresponding figures were 61 and $84 \%$ respectively. Although statistically not significant, patients who received RT showed better outcome, with a median overall survival of 41 months. Similar to other studies, we noted better outcome in patients with epithelioid morphology $(14,20)$.

We acknowledge the inherent weaknesses and limitations of our retrospective study. The comparison of OS and DFS outcomes in patients who received RT and those who did not is subject to bias because of underlying factors that portend a worse prognosis. The small number of patients studied over a decade long period serves only to highlight the rarity of the disease. While, adjuvant RT after EPP allows optimal dose to be delivered to the tumour bed with a lower risk of toxicity, as the ipsilateral lung is removed, recently some centres have also explored the use of lung sparing hemithoracic RT to the pleural surface alone after P/D. Studies evaluating this technique, known as intensity modulated pleural radiation therapy (IMPRINT) have reported 
medRxiv preprint doi: https://doi.org/10.1101/2020.05.13.20087189; this version posted May 18, 2020. The copyright holder for this preprint (which was not certified by peer review) is the author/funder, who has granted medRxiv a license to display the preprint in perpetuity.

All rights reserved. No reuse allowed without permission.

it to be safe with no incidence of grade 3/4 pneumonitis(25). Neoadjuvant accelerated RT before surgery is also a promising approach which few centres have studied with success $(26,27)$. Immunotherapy has already shown some potential in the systemic treatment of MPM(28-30) and hopefully would bring about a paradigm shift as it has in the management of non-small cell lung cancer.

With a lack of acceptability and consensus on optimal treatment, complex, arduous surgery and precise radiation procedures, MPM continues to baffle thoracic oncologists with sobering outcomes. Tri-modality treatment of MPM is an aggressive treatment strategy; despite the extensiveness of surgery and complexity of hemi-thoracic RT, we demonstrated excellent dosimetry, toxicity profile, favourable outcomes and promising median overall survival in nonmetastatic MPM.

Although the exact and definite role of radiotherapy in the treatment paradigm of mesothelioma remains to be defined, increasing evidence supports the fact that mesothelioma is sensitive to radiotherapy treatment(22). With this account of institutional treatment outcomes, our study adds to the existing literature supporting the efficacy of trimodality therapy in the treatment of MPM, bringing about renewed hope for this rare malignancy.

\section{REFERENCES}

1. Robinson BWS, Musk AW, Lake RA. Malignant mesothelioma. Lancet Lond Engl. 2005 Aug 30;366(9483):397-408.

2. Cramer G, Simone CB, Busch TM, Cengel KA. Adjuvant, neoadjuvant, and definitive radiation therapy for malignant pleural mesothelioma. J Thorac Dis. 2018 Aug;10(Suppl 21):S2565-73.

3. Patel SC, Dowell JE. Modern management of malignant pleural mesothelioma. Lung Cancer Targets Ther. 2016 May 3;7:63-72.

4. Van Schil PE, Baas P, Gaafar R, Maat AP, Van de Pol M, Hasan B, et al. Trimodality therapy for malignant pleural mesothelioma: results from an EORTC phase II multicentre trial. Eur Respir J. 2010 Dec;36(6):1362-9. 
medRxiv preprint doi: https://doi.org/10.1101/2020.05.13.20087189; this version posted May 18, 2020. The copyright holder for this preprint (which was not certified by peer review) is the author/funder, who has granted medRxiv a license to display the preprint in perpetuity.

5. Nelson DB, Rice DC, Niu J, Atay S, Vaporciyan AA, Antonoff M, et al. Long-Term Survival Outcomes of Cancer-Directed Surgery for Malignant Pleural Mesothelioma: Propensity Score Matching Analysis. J Clin Oncol Off J Am Soc Clin Oncol. 2017 Oct 10;35(29):3354-62.

6. Treasure T, Lang-Lazdunski L, Waller D, Bliss JM, Tan C, Entwisle J, et al. Extrapleural pneumonectomy versus no extra-pleural pneumonectomy for patients with malignant pleural mesothelioma: clinical outcomes of the Mesothelioma and Radical Surgery (MARS) randomised feasibility study. Lancet Oncol. 2011 Aug;12(8):763-72.

7. Katzman D, Sterman DH. Updates in the diagnosis and treatment of malignant pleural mesothelioma. Curr Opin Pulm Med. 2018;24(4):319-26.

8. Stahel RA, Riesterer O, Xyrafas A, Opitz I, Beyeler M, Ochsenbein A, et al. Neoadjuvant chemotherapy and extrapleural pneumonectomy of malignant pleural mesothelioma with or without hemithoracic radiotherapy (SAKK 17/04): a randomised, international, multicentre phase 2 trial. Lancet Oncol. 2015;16(16):1651-8.

9. Yan TD, Cao CQ, Boyer M, Tin MM, Kennedy C, McLean J, et al. Improving survival results after surgical management of malignant pleural mesothelioma: an Australian institution experience. Ann Thorac Cardiovasc Surg Off J Assoc Thorac Cardiovasc Surg Asia. 2011;17(3):243-9.

10. Teh E, Fiorentino F, Tan C, Treasure T. A systematic review of lung-sparing extirpative surgery for pleural mesothelioma. J R Soc Med. 2011 Feb;104(2):69-80.

11. Cao C, Tian D, Park J, Allan J, Pataky KA, Yan TD. A systematic review and metaanalysis of surgical treatments for malignant pleural mesothelioma. Lung Cancer Amst Neth. 2014 Feb;83(2):240-5.

12. Taioli E, Wolf AS, Camacho-Rivera M, Kaufman A, Lee D-S, Nicastri D, et al. Determinants of Survival in Malignant Pleural Mesothelioma: A Surveillance, Epidemiology, and End Results (SEER) Study of 14,228 Patients. PloS One. 2015;10(12):e0145039.

13. Flores RM, Pass HI, Seshan VE, Dycoco J, Zakowski M, Carbone M, et al. Extrapleural pneumonectomy versus pleurectomy/decortication in the surgical management of malignant 
medRxiv preprint doi: https://doi.org/10.1101/2020.05.13.20087189; this version posted May 18, 2020. The copyright holder for this preprint (which was not certified by peer review) is the author/funder, who has granted medRxiv a license to display the preprint in perpetuity.

All rights reserved. No reuse allowed without permission.

pleural mesothelioma: results in 663 patients. J Thorac Cardiovasc Surg. 2008 Mar;135(3):620_ $6,626-3$.

14. Rice DC, Stevens CW, Correa AM, Vaporciyan AA, Tsao A, Forster KM, et al. Outcomes after extrapleural pneumonectomy and intensity-modulated radiation therapy for malignant pleural mesothelioma. Ann Thorac Surg. 2007 Nov;84(5):1685-1692-1693.

15. Saddoughi SA, Abdelsattar ZM, Blackmon SH. National Trends in the Epidemiology of Malignant Pleural Mesothelioma: A National Cancer Data Base Study. Ann Thorac Surg. 2018 Feb;105(2):432-7.

16. Mahmoudi. Evaluation of the photon dose calculation accuracy in radiation therapy of malignant pleural mesothelioma [Internet]. [cited 2020 Apr 30]. Available from: http://www.cancerjournal.net/article.asp?issn=09731482; year=2018; volume=14;issue=5; spage=1029; epage=1035; aulast=Mahmoudi

17. Allen AM, Czerminska M, Jänne PA, Sugarbaker DJ, Bueno R, Harris JR, et al. Fatal pneumonitis associated with intensity-modulated radiation therapy for mesothelioma. Int $\mathbf{J}$ Radiat Oncol Biol Phys. 2006 Jul 1;65(3):640-5.

18. Krayenbuehl J, Oertel S, Davis JB, Ciernik IF. Combined photon and electron threedimensional conformal versus intensity-modulated radiotherapy with integrated boost for adjuvant treatment of malignant pleural mesothelioma after pleuropneumonectomy. Int $\mathrm{J}$ Radiat Oncol Biol Phys. 2007 Dec 1;69(5):1593-9.

19. Hill-Kayser CE, Avery S, Mesina CF, James P, Friedberg JS, Cengel K, et al.

Hemithoracic radiotherapy after extrapleural pneumonectomy for malignant pleural mesothelioma: a dosimetric comparison of two well-described techniques. J Thorac Oncol Off Publ Int Assoc Study Lung Cancer. 2009 Nov;4(11):1431-7.

20. Gomez DR, Zhung JE, Gomez J, Chan K, Wu AJ, Wolden SL, et al. Intensity-Modulated Radiotherapy in Postoperative Treatment of Oral Cavity Cancers. Int J Radiat Oncol • Biol • Phys. 2009 Mar 15;73(4):1096-103. 
medRxiv preprint doi: https://doi.org/10.1101/2020.05.13.20087189; this version posted May 18, 2020. The copyright holder for this preprint (which was not certified by peer review) is the author/funder, who has granted medRxiv a license to display the preprint in perpetuity.

All rights reserved. No reuse allowed without permission.

21. Kimura T, Doi Y, Nakashima T, Imano N, Katsuta T, Takahashi S, et al. Clinical experience of volumetric modulated arc therapy for malignant pleural mesothelioma after extrapleural pneumonectomy. J Radiat Res (Tokyo). 2015 Mar;56(2):315-24.

22. Perrot $\mathrm{M}$ de, $\mathrm{Wu} \mathrm{L}, \mathrm{Wu} \mathrm{M}$, Cho BCJ. Radiotherapy for the treatment of malignant pleural mesothelioma. Lancet Oncol. 2017;18(9):e532-42.

23. Clive AO, Taylor H, Dobson L, Wilson P, de Winton E, Panakis N, et al. Prophylactic radiotherapy for the prevention of procedure-tract metastases after surgical and large-bore pleural procedures in malignant pleural mesothelioma (SMART): a multicentre, open-label, phase 3, randomised controlled trial. Lancet Oncol. 2016 Aug;17(8):1094-104.

24. Riesterer O, Ciernik IF, Stahel RA, Xyrafas A, Aebersold DM, Plasswilm L, et al. Pattern of failure after adjuvant radiotherapy following extrapleural pneumonectomy of pleural mesothelioma in the SAKK 17/04 trial. Radiother Oncol J Eur Soc Ther Radiol Oncol. 2019;138:121-5.

25. Rimner A, Zauderer MG, Gomez DR, Adusumilli PS, Parhar PK, Wu AJ, et al. Phase II Study of Hemithoracic Intensity-Modulated Pleural Radiation Therapy (IMPRINT) As Part of Lung-Sparing Multimodality Therapy in Patients With Malignant Pleural Mesothelioma. J Clin Oncol Off J Am Soc Clin Oncol. 2016 10;34(23):2761-8.

26. de Perrot M, Feld R, Leighl NB, Hope A, Waddell TK, Keshavjee S, et al. Accelerated hemithoracic radiation followed by extrapleural pneumonectomy for malignant pleural mesothelioma. J Thorac Cardiovasc Surg. 2016 Feb;151(2):468-73.

27. Hong JH, Lee HC, Choi KH, Moon SW, Kim KS, Hong SH, et al. Preliminary results of entire pleural intensity-modulated radiotherapy in a neoadjuvant setting for resectable malignant mesothelioma. Radiat Oncol J. 2019 Jun;37(2):101-9.

28. Alley EW, Lopez J, Santoro A, Morosky A, Saraf S, Piperdi B, et al. Clinical safety and activity of pembrolizumab in patients with malignant pleural mesothelioma (KEYNOTE-028): preliminary results from a non-randomised, open-label, phase 1b trial. Lancet Oncol. 2017;18(5):623-30. 
medRxiv preprint doi: https://doi.org/10.1101/2020.05.13.20087189; this version posted May 18, 2020. The copyright holder for this preprint (which was not certified by peer review) is the author/funder, who has granted medRxiv a license to display the preprint in perpetuity.

All rights reserved. No reuse allowed without permission.

29. Scherpereel A, Mazieres J, Greillier L, Dô P, Bylicki O, Monnet I, et al. Second- or thirdline nivolumab (Nivo) versus nivo plus ipilimumab (Ipi) in malignant pleural mesothelioma

(MPM) patients: Results of the IFCT-1501 MAPS2 randomized phase II trial. J Clin Oncol. 2017 Jun 13;35(18_suppl):LBA8507-LBA8507.

30. Quispel-Janssen J, van der Noort V, de Vries JF, Zimmerman M, Lalezari F, Thunnissen E, et al. Programmed Death 1 Blockade With Nivolumab in Patients With Recurrent Malignant Pleural Mesothelioma. J Thorac Oncol Off Publ Int Assoc Study Lung Cancer.

2018;13(10):1569-76.

Figures Legend:

Figure 1. Dose distribution of a typical hemithoracic IMRT plan

Figure 2. Disease free survival (DFS)

Figure 3a. Overall survival (OS)

Figure 3b. Overall survival (OS) in patients who received RT vs no RT

\section{Tables Legend:}

Table 1 Patient characteristics $(n=21)$

Table 2. RT Dose parameters

Table 3. RT toxicity of individual patients 
medRxiv preprint doi: https://doi.org/10.1101/2020.05.13.20087189; this version posted May 18, 2020. The copyright holder for this preprint (which was not certified by peer review) is the author/funder, who has granted medRxiv a license to display the preprint in perpetuity.

All rights reserved. No reuse allowed without permission.

Figure 1. Dose distribution of a typical hemithoracic IMRT plan

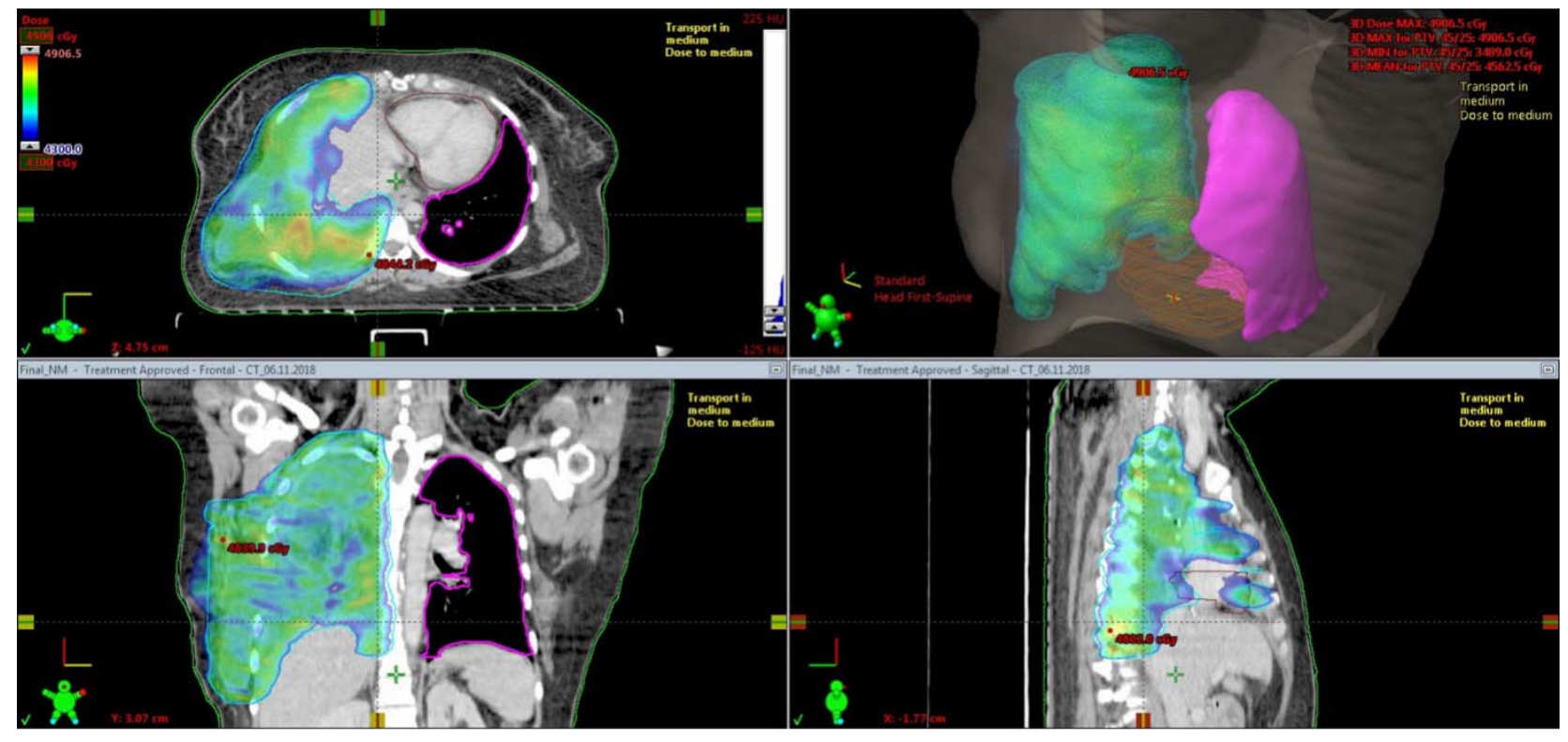


medRxiv preprint doi: https://doi.org/10.1101/2020.05.13.20087189; this version posted May 18,2020 . The copyright holder for this preprint (which was not certified by peer review) is the author/funder, who has granted medRxiv a license to display the preprint in perpetuity.

All rights reserved. No reuse allowed without permission.

Figure 2. Disease free survival (DFS)

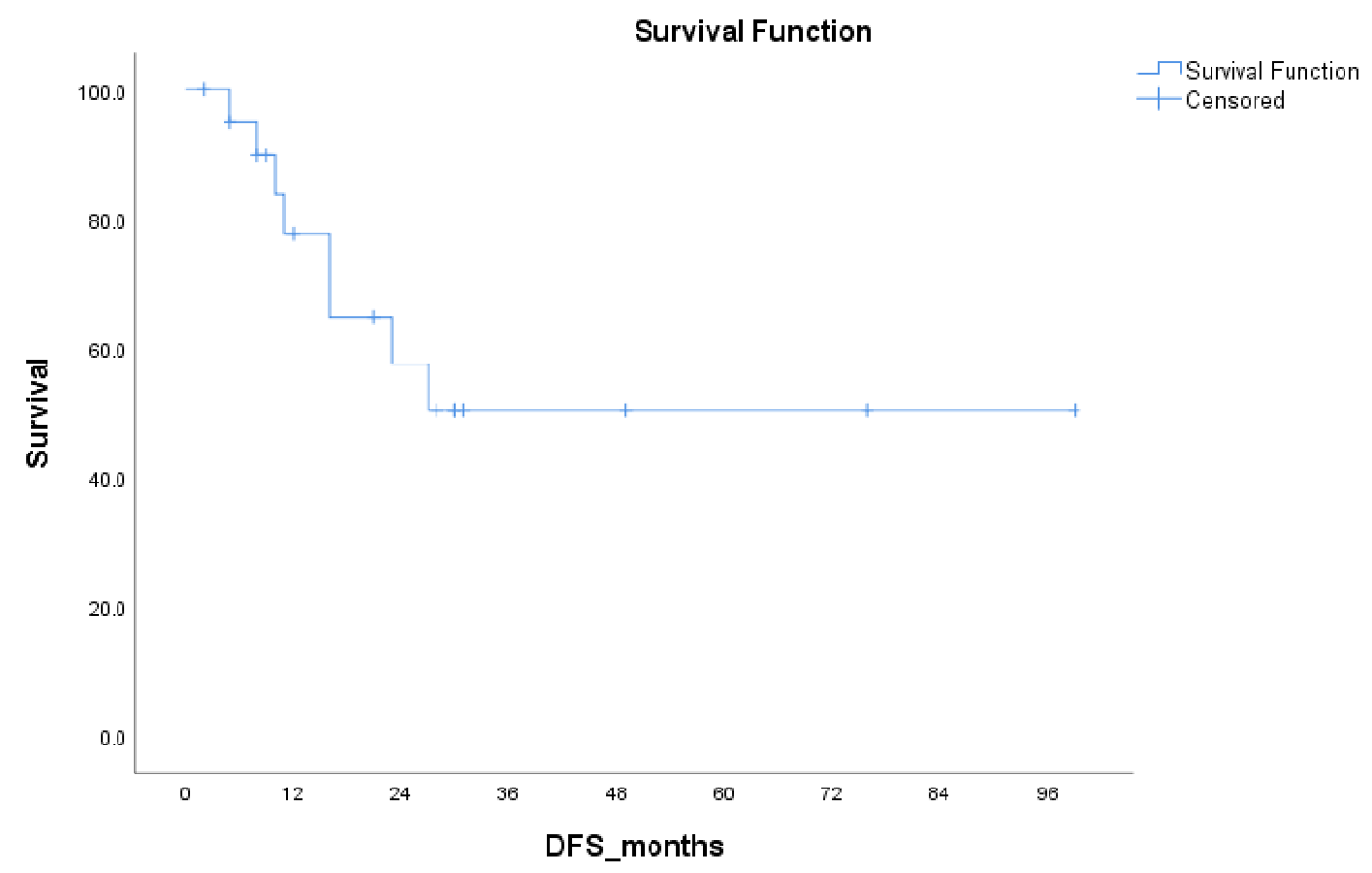


medRxiv preprint doi: https://doi.org/10.1101/2020.05.13.20087189; this version posted May 18, 2020. The copyright holder for this preprint (which was not certified by peer review) is the author/funder, who has granted medRxiv a license to display the preprint in perpetuity.

All rights reserved. No reuse allowed without permission.

Figure 3a. Overall survival (OS)

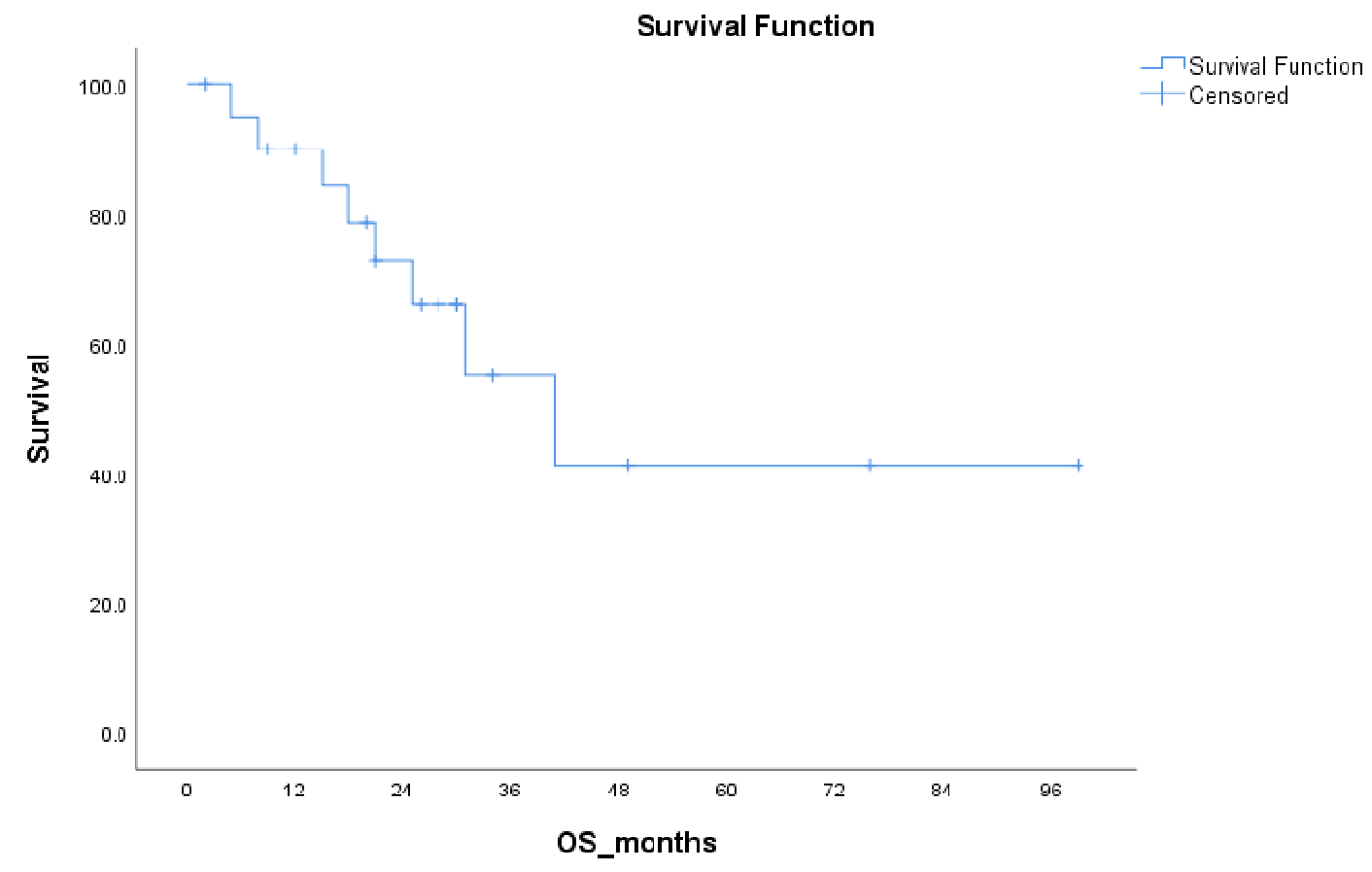

Figure 3b. Overall survival (OS) in patients who received RT vs no RT 


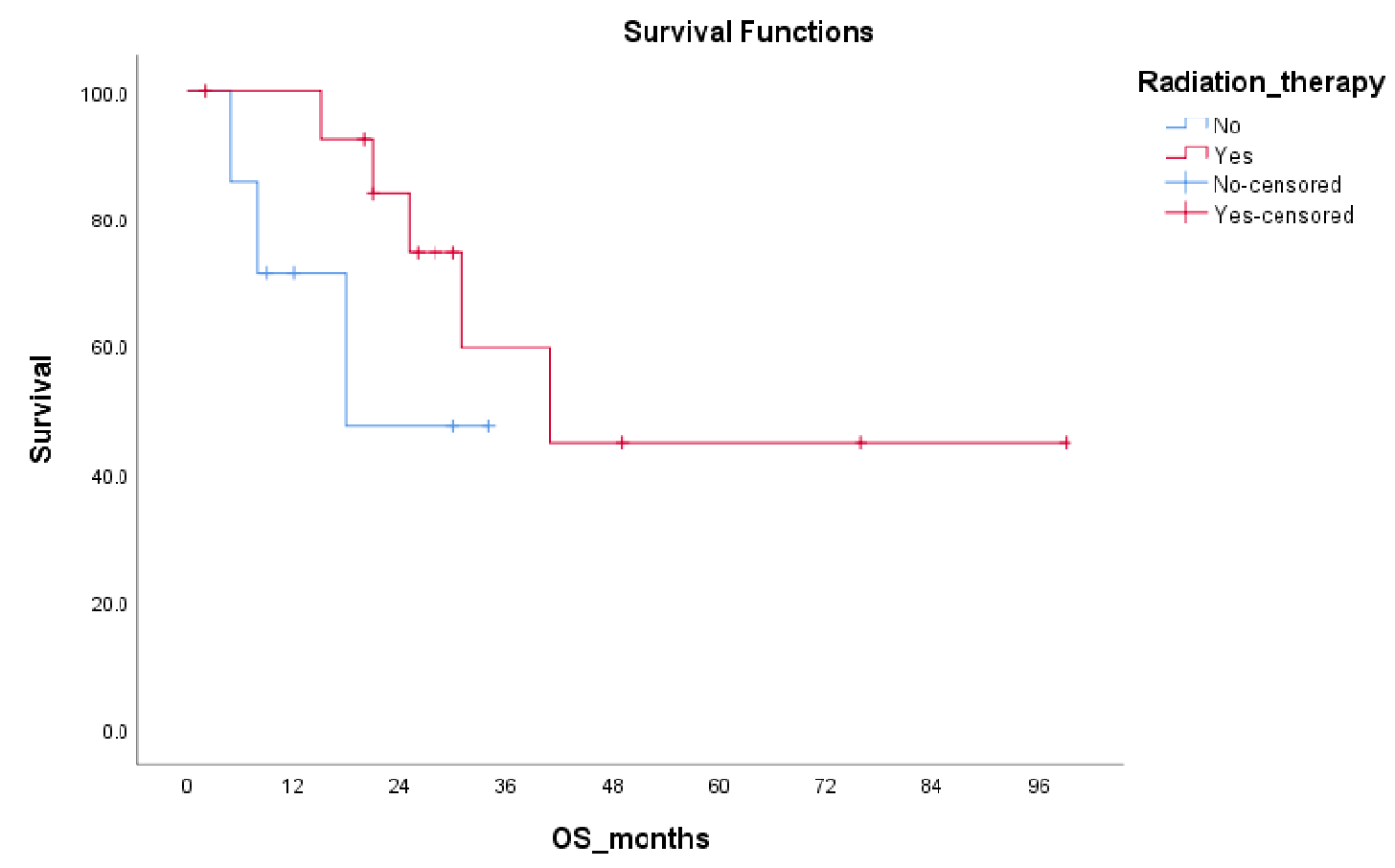

\begin{tabular}{|c|c|}
\hline \multicolumn{2}{|c|}{ Table 1 Patient characteristics $(n=21)$} \\
\hline Character & Frequency \\
\hline \multicolumn{2}{|l|}{ Gender } \\
\hline Male & 17 \\
\hline Female & 4 \\
\hline Age at diagnosis & $\begin{array}{l}\text { Median }-53 \text { years; } \\
\text { range } 17-71 \text { years }\end{array}$ \\
\hline \multicolumn{2}{|l|}{ Smoker } \\
\hline Yes & 3 \\
\hline No & 14 \\
\hline Tobacco chewer & 4 \\
\hline \multicolumn{2}{|l|}{ Histology } \\
\hline Epithelioid & 17 \\
\hline Sarcomatoid & 1 \\
\hline Mixed & 3 \\
\hline \multicolumn{2}{|l|}{ Laterality } \\
\hline Right & 11 \\
\hline Left & 10 \\
\hline \multicolumn{2}{|l|}{ T stage } \\
\hline $\mathrm{T} 1$ & 1 \\
\hline
\end{tabular}




\begin{tabular}{|c|c|}
\hline 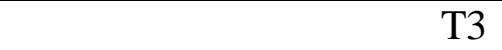 & 9 \\
\hline \multicolumn{2}{|l|}{ N stage } \\
\hline No & 10 \\
\hline N1 & 11 \\
\hline \multicolumn{2}{|l|}{ NACT } \\
\hline Yes & 19 \\
\hline No & 2 \\
\hline \multicolumn{2}{|l|}{ Surgery } \\
\hline EPP & 16 \\
\hline Others & 5 \\
\hline
\end{tabular}

\section{Table 2. Dose parameters}

\begin{tabular}{|c|c|c|c|}
\hline \multirow[t]{2}{*}{ Parameter } & \multicolumn{3}{|c|}{ Mean \pm standard deviation } \\
\hline & All patients $(n=10)$ & RIGHT $(n=5)$ & LEFT $(n=5)$ \\
\hline \multicolumn{4}{|l|}{ Contralateral lung } \\
\hline Volume(cc) & 1197.44 & 1068.72 & 1326.16 \\
\hline Mean dose(Gy) & $5.95 \pm 1.74$ & $5.53 \pm 1.48$ & $6.37 \pm 2.05$ \\
\hline $\mathrm{V}_{5 \mathrm{~Gy}}(\%)$ & $42.82 \pm 23.31$ & $46.74 \pm 30.87$ & $38.90 \pm 15.21$ \\
\hline $\mathrm{V}_{10 \mathrm{~Gy}}(\%)$ & $7.49 \pm 5.35$ & $13.78 \pm 7.32$ & $7.65 \pm 6.30$ \\
\hline $\mathrm{V}_{20 \mathrm{~Gy}}(\%)$ & $0.42 \pm 1.03$ & $0.77 \pm 1.43$ & $0.08 \pm 0.17$ \\
\hline \multicolumn{4}{|l|}{ Heart } \\
\hline Mean Dose(Gy) & $20.55 \pm 3.54$ & $19.18 \pm 3.16$ & $21.92 \pm 3.67$ \\
\hline $\mathrm{V}_{10 \mathrm{~Gy}}(\%)$ & $70.56 \pm 18.23$ & $67.60 \pm 20.17$ & $75.53 \pm 17.86$ \\
\hline $\mathrm{V}_{20 \mathrm{~Gy}}(\%)$ & $40.02 \pm 11.08$ & $36.65 \pm 9.66$ & $43.40 \pm 12.43$ \\
\hline $\mathrm{V}_{30 \mathrm{~Gy}}(\%)$ & $26.25 \pm 7.62$ & $23.36 \pm 6.69$ & $29.15 \pm 8.07$ \\
\hline \multicolumn{4}{|l|}{ Liver } \\
\hline Dmean & $13.99 \pm 6.97$ & $19.34 \pm 3.57$ & $7.29 \pm 2.24$ \\
\hline
\end{tabular}




\begin{tabular}{|r|l|l|l|}
\hline $\mathrm{V}_{\text {20Gy }}(\%)$ & $28.29 \pm 21.34$ & $44.89 \pm 10.73$ & $7.54 \pm 5.33$ \\
\hline${ }_{\text {V30Gy }}(\%)$ & $16.15 \pm 14.59$ & $27.15 \pm 8.85$ & $2.39 \pm 3.05$ \\
\hline v40Gy $(\%)$ & $9.06 \pm 8.80$ & $15.14 \pm 6.86$ & $1.46 \pm 2.28$ \\
\hline & & & \\
\hline PTV & & $2531.43 \pm 974.93$ & $2076.30 \pm 949.03$ \\
\hline Volume (cc) & $2303.86 \pm 938.23$ & $46.65 \pm 2.20$ & $47.78 \pm 3.29$ \\
\hline Dmean(Gy) & $47.21 \pm 2.71$ & $30.85 \pm 6.73$ & $32.32 \pm 3.35$ \\
\hline Dmin(Gy) & $31.59 \pm 5.07$ & $49.78 \pm 2.62$ & $51.20 \pm 4.17$ \\
\hline Dmax(Gy) & $50.49 \pm 3.37$ & $48.18 \pm 2.38$ & $49.02 \pm 3.67$ \\
\hline D2(Gy) & $48.60 \pm 2.95$ & $43.39 \pm 0.62$ & $45.72 \pm 3.07$ \\
\hline D98(Gy) & $44.55 \pm 2.42$ & &
\end{tabular}

\begin{tabular}{|c|c|c|}
\hline \multicolumn{2}{|c|}{ Table 3. RT toxicity of individual patients } \\
\hline \multirow{2}{*}{ Patient } & \multicolumn{2}{|c|}{ Toxicity } \\
\cline { 2 - 3 } & Acute & Late \\
\hline 1 & Gr I Pneumonitis & None \\
\hline 2 & Gr II Pneumonitis & None \\
\hline 3 & None & None \\
\hline 4 & Gr I Oesophagitis & None \\
\hline 5 & Gr I Pneumonitis & None \\
\hline 6 & None & None \\
\hline 7 & Gr I Pneumonitis & None \\
\hline 8 & Gr II Oesophagitis & None \\
\hline 9 & Gr I Oesophagitis & None \\
\hline 10 & & None \\
\hline
\end{tabular}


medRxiv preprint doi: https://doi.org/10.1101/2020.05.13.20087189; this version posted May 18, 2020. The copyright holder for this preprint (which was not certified by peer review) is the author/funder, who has granted medRxiv a license to display the preprint in perpetuity.

All rights reserved. No reuse allowed without permission. 
medRxiv preprint doi: https://doi.org/10.1101/2020.05.13.20087189; this version posted May 18, 2020. The copyright holder for this preprint (which was not certified by peer review) is the author/funder, who has granted medRxiv a license to display the preprint in perpetuity.

All rights reserved. No reuse allowed without permission.

Figure 1. Dose distribution of a typical hemithoracic IMRT plan

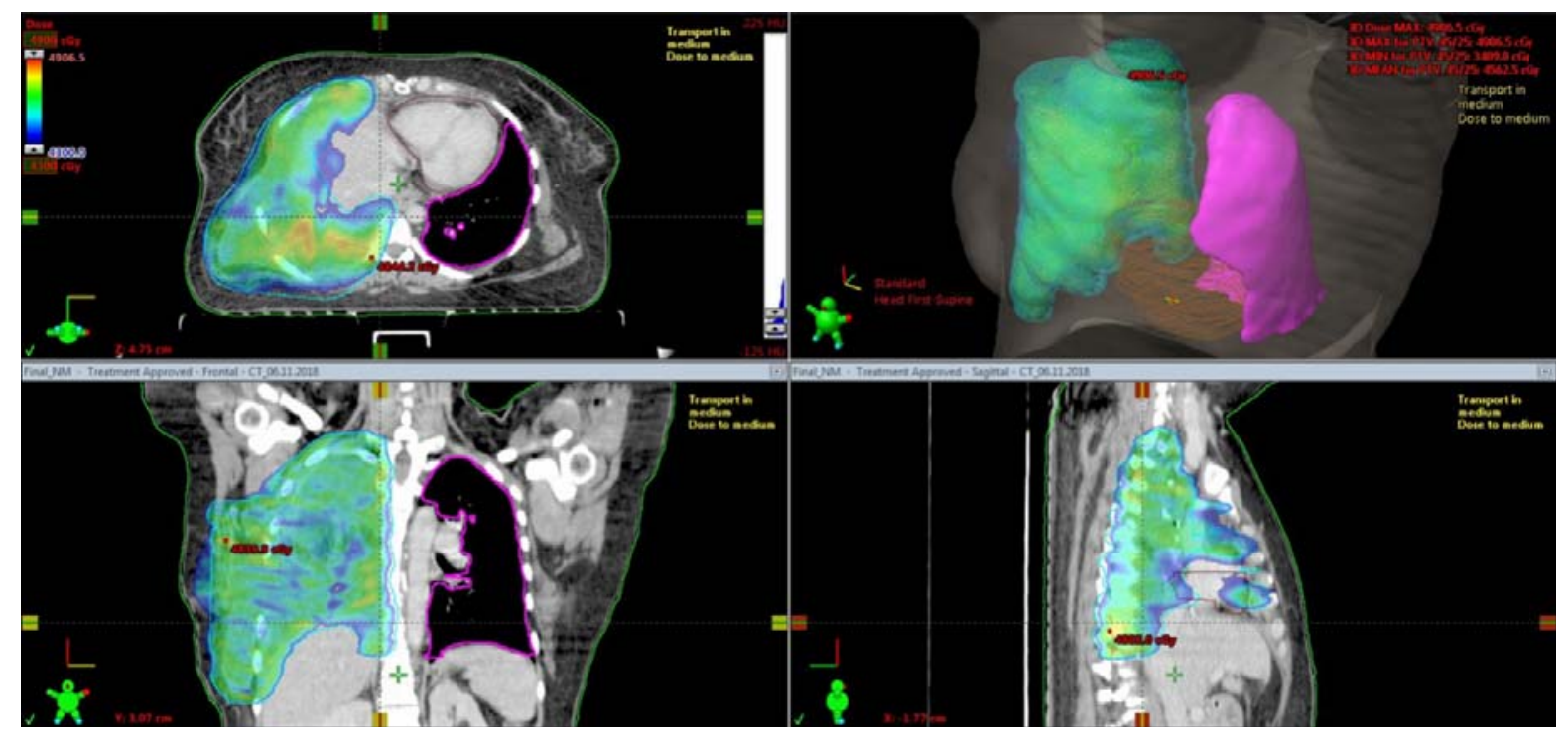


medRxiv preprint doi: https://doi.org/10.1101/2020.05.13.20087189; this version posted May 18, 2020. The copyright holder for this preprint (which was not certified by peer review) is the author/funder, who has granted medRxiv a license to display the preprint in perpetuity.

All rights reserved. No reuse allowed without permission.

Figure 2. Disease free survival (DFS)

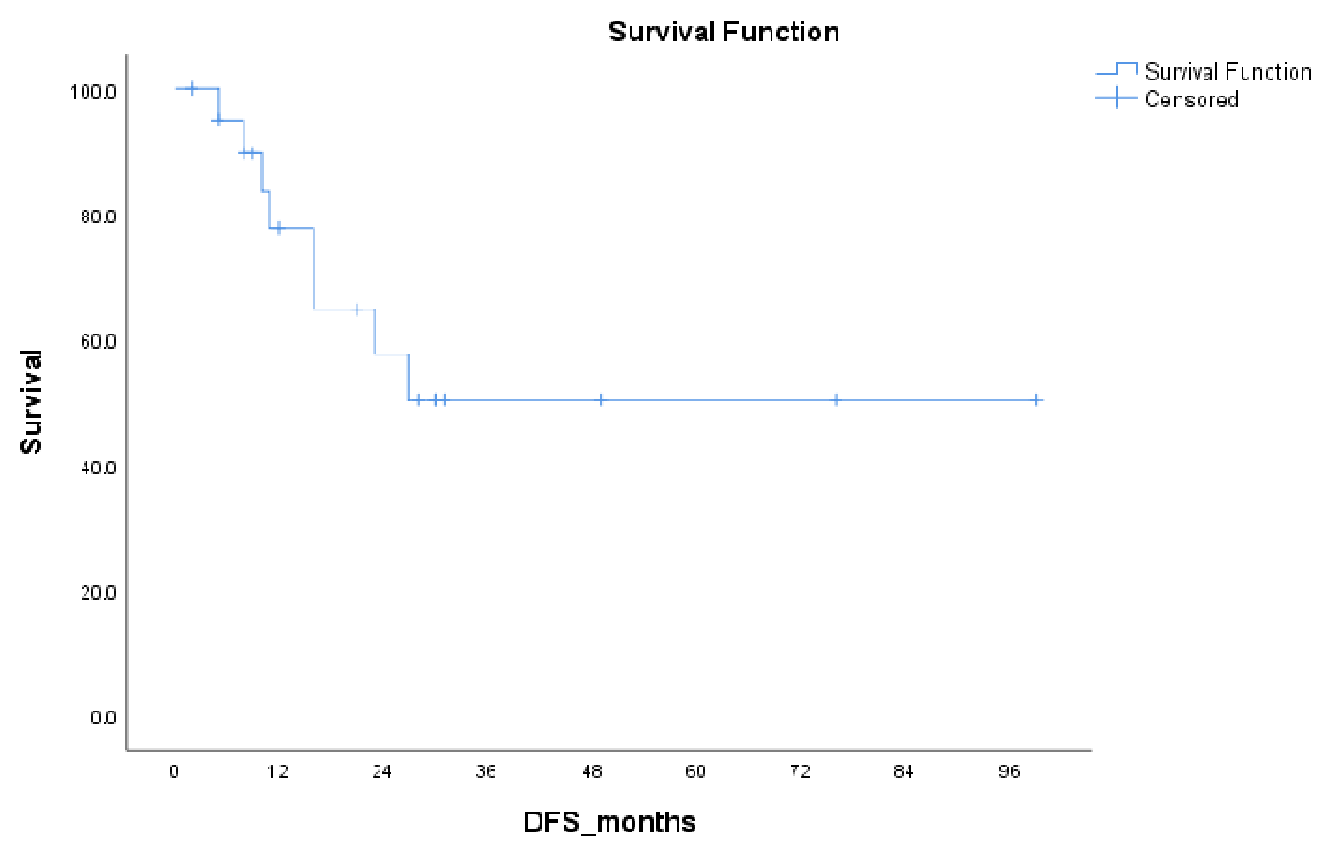


medRxiv preprint doi: https://doi.org/10.1101/2020.05.13.20087189; this version posted May 18, 2020. The copyright holder for this preprint (which was not certified by peer review) is the author/funder, who has granted medRxiv a license to display the preprint in perpetuity. All rights reserved. No reuse allowed without permission.

Figure 3a. Overall survival (OS)

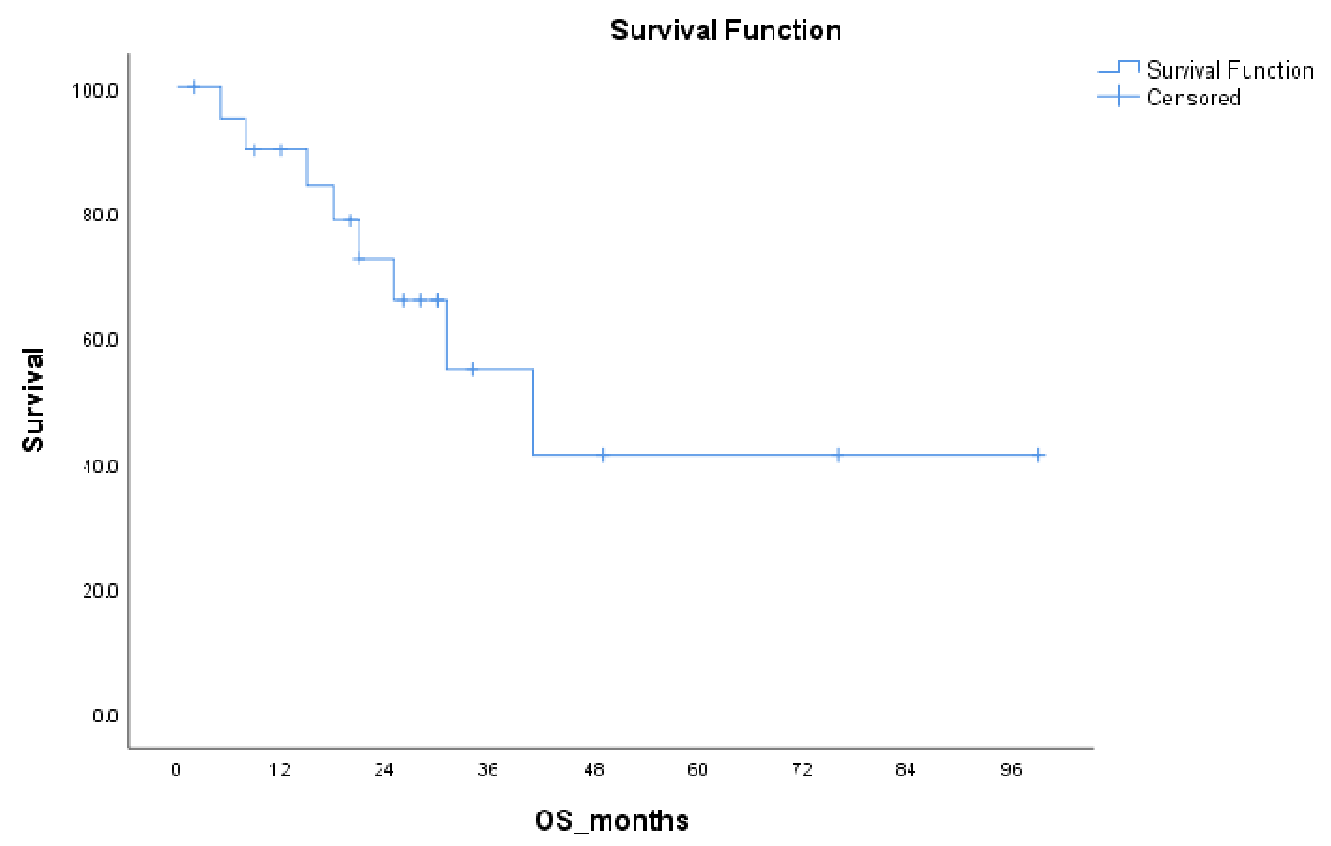

Figure 3b. Overall survival (OS) in patients who received RT vs no RT

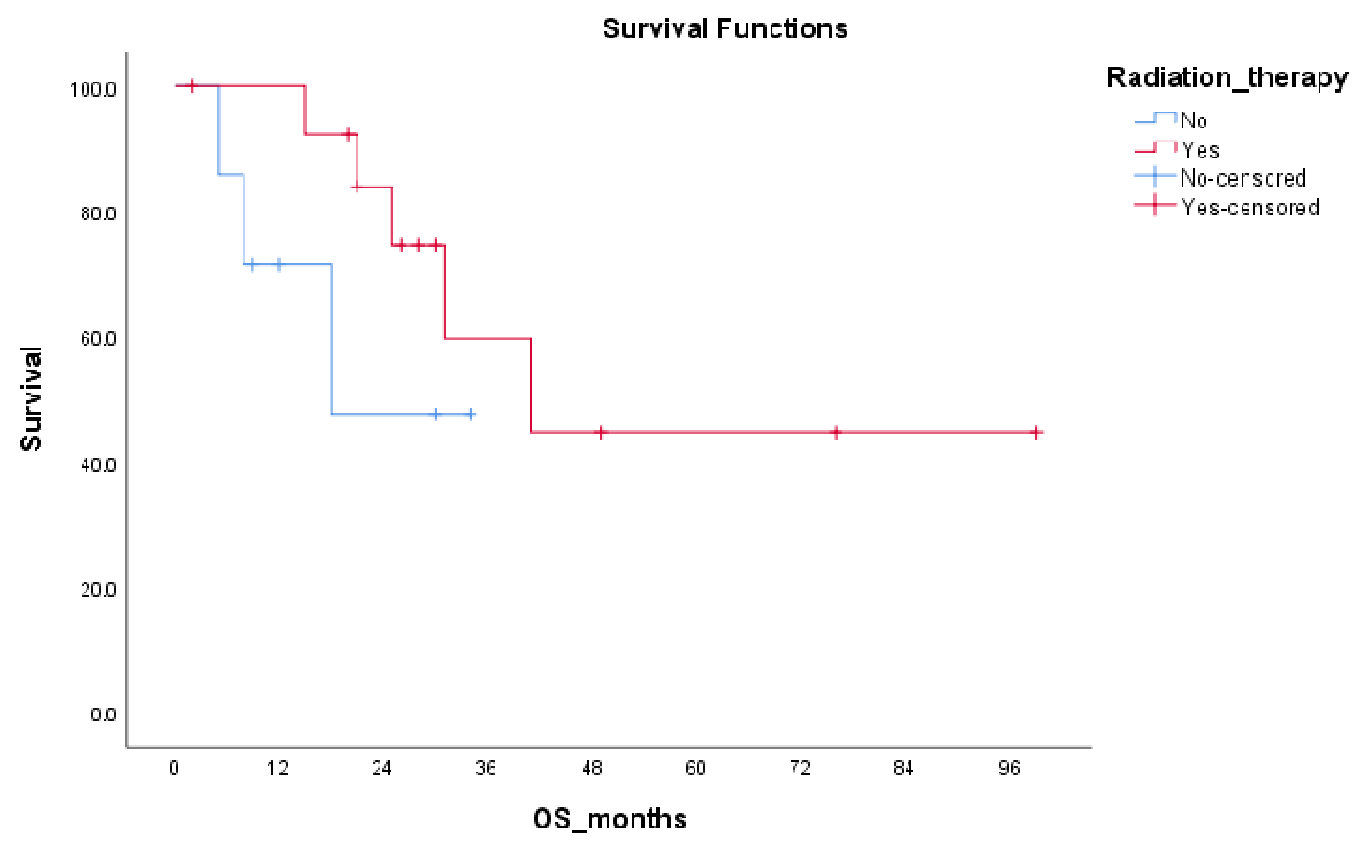


medRxiv preprint doi: https://doi.org/10.1101/2020.05.13.20087189; this version posted May 18, 2020. The copyright holder for this preprint (which was not certified by peer review) is the author/funder, who has granted medRxiv a license to display the preprint in perpetuity.

All rights reserved. No reuse allowed without permission.

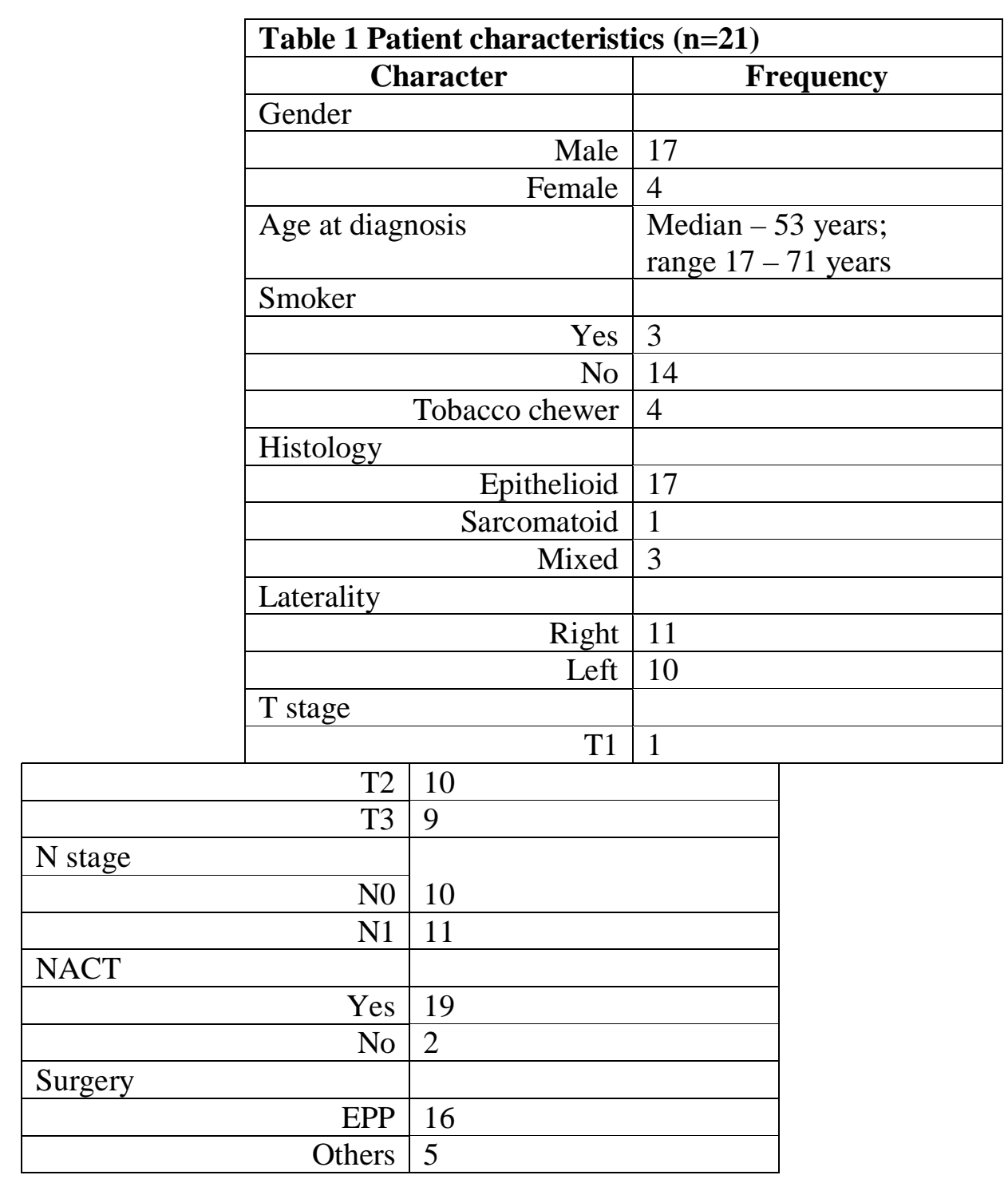


medRxiv preprint doi: https://doi.org/10.1101/2020.05.13.20087189; this version posted May 18, 2020. The copyright holder for this preprint (which was not certified by peer review) is the author/funder, who has granted medRxiv a license to display the preprint in perpetuity.

\begin{tabular}{|c|c|c|c|}
\hline \multirow[t]{2}{*}{ Parameter } & \multicolumn{3}{|c|}{ Mean \pm standard deviation } \\
\hline & All patients $(\mathrm{n}=10)$ & RIGHT (n = 5) & LEFT (n = 5) \\
\hline \multicolumn{4}{|l|}{ Contralateral lung } \\
\hline Volume(cc) & 1197.44 & 1068.72 & 1326.16 \\
\hline Mean dose(Gy) & $5.95 \pm 1.74$ & $5.53 \pm 1.48$ & $6.37 \pm 2.05$ \\
\hline $\mathrm{V}_{5 \mathrm{~Gy}}(\%)$ & $42.82 \pm 23.31$ & $46.74 \pm 30.87$ & $38.90 \pm 15.21$ \\
\hline $\mathrm{V}_{10 \mathrm{~Gy}}(\%)$ & $7.49 \pm 5.35$ & $13.78 \pm 7.32$ & $7.65 \pm 6.30$ \\
\hline $\mathrm{V}_{20 \mathrm{~Gy}}(\%)$ & $0.42 \pm 1.03$ & $0.77 \pm 1.43$ & $0.08 \pm 0.17$ \\
\hline \multicolumn{4}{|l|}{ Heart } \\
\hline Mean Dose(Gy) & $20.55 \pm 3.54$ & $19.18 \pm 3.16$ & $21.92 \pm 3.67$ \\
\hline $\mathrm{V}_{10 \mathrm{~Gy}}(\%)$ & $70.56 \pm 18.23$ & $67.60 \pm 20.17$ & $75.53 \pm 17.86$ \\
\hline $\mathrm{V}_{20 \mathrm{~Gy}}(\%)$ & $40.02 \pm 11.08$ & $36.65 \pm 9.66$ & $43.40 \pm 12.43$ \\
\hline $\mathrm{V}_{30 \mathrm{~Gy}}(\%)$ & $26.25 \pm 7.62$ & $23.36 \pm 6.69$ & $29.15 \pm 8.07$ \\
\hline \multicolumn{4}{|l|}{ Liver } \\
\hline Dmean & $13.99 \pm 6.97$ & $19.34 \pm 3.57$ & $7.29 \pm 2.24$ \\
\hline $\mathrm{V}_{20 \mathrm{~Gy}}(\%)$ & $28.29 \pm 21.34$ & $44.89 \pm 10.73$ & $7.54 \pm 5.33$ \\
\hline V30Gy $(\%)$ & $16.15 \pm 14.59$ & $27.15 \pm 8.85$ & $2.39 \pm 3.05$ \\
\hline $\mathrm{V} 40 \mathrm{~Gy}(\%)$ & $9.06 \pm 8.80$ & $15.14 \pm 6.86$ & $1.46 \pm 2.28$ \\
\hline \multicolumn{4}{|l|}{ PTV } \\
\hline Volume (cc) & $2303.86 \pm 938.23$ & $2531.43 \pm 974.93$ & $2076.30 \pm 949.03$ \\
\hline Dmean(Gy) & $47.21 \pm 2.71$ & $46.65 \pm 2.20$ & $47.78 \pm 3.29$ \\
\hline $\operatorname{Dmin}(\mathrm{Gy})$ & $31.59 \pm 5.07$ & $30.85 \pm 6.73$ & $32.32 \pm 3.35$ \\
\hline $\operatorname{Dmax}(\mathrm{Gy})$ & $50.49 \pm 3.37$ & $49.78 \pm 2.62$ & $51.20 \pm 4.17$ \\
\hline D2(Gy) & $48.60 \pm 2.95$ & $48.18 \pm 2.38$ & $49.02 \pm 3.67$ \\
\hline D98(Gy) & $44.55 \pm 2.42$ & $43.39 \pm 0.62$ & $45.72 \pm 3.07$ \\
\hline
\end{tabular}


medRxiv preprint doi: https://doi.org/10.1101/2020.05.13.20087189; this version posted May 18, 2020. The copyright holder for this preprint (which was not certified by peer review) is the author/funder, who has granted medRxiv a license to display the preprint in perpetuity.

All rights reserved. No reuse allowed without permission.

\begin{tabular}{|c|c|c|}
\hline \multicolumn{2}{|c|}{ Table 3. RT toxicity of individual patients } \\
\hline \multirow{2}{*}{ Patient } & \multicolumn{2}{|c|}{ Toxicity } \\
\cline { 2 - 3 } & Acute & Late \\
\hline 1 & Gr I Pneumonitis & None \\
\hline 2 & Gr II Pneumonitis & None \\
\hline 3 & None & None \\
\hline 4 & Gr I Oesophagitis & None \\
\hline 5 & Gr I Pneumonitis & None \\
\hline 6 & None & None \\
\hline 7 & Gr I Pneumonitis & None \\
\hline 8 & Gr II Oesophagitis & None \\
\hline 9 & Gr I Oesophagitis & None \\
\hline 10 & None & None \\
\hline
\end{tabular}

